\title{
Penerapan Sistem Daya Cadangan Untuk Lemari Vaksin Menggunakan PLTS Pada Puskesmas Sindangbarang Bogor
}

\author{
Hasna Satya Dini ${ }^{1}$; Muhamamd Imbarothur Mowaviq ${ }^{2}$; Sugeng Purwanto ${ }^{3}$; Andi Junaidi ${ }^{4}$; \\ Pawenary $^{5}$; Sofitri Rahayu ${ }^{6}$ \\ 1,2,3,4,5,6 Institut Teknologi PLN \\ ${ }^{1}$ hasna@itpln.ac.id
}

\begin{abstract}
The temperature stability of the vaccine needs to be designed in such a way as to maintain its quality. Where vaccines are generally placed in a special refrigerator with an internal temperature of around $+2^{\circ} \mathrm{C}-+8^{0} \mathrm{C}$. The condition of the electricity network in the Bogor area, which sometimes goes out for a long time can cause electricity to not be supplied for vaccine refrigerators. For a long period of time, this condition can cause damage to the vaccine so that it cannot be given to toddlers. This activity is the application of technology that is very useful for the people of the Bogor, especially for the Sindangbarang Health Center in Bogor related to the design of power reserves, especially for vaccine refrigerators. This power backup system uses various equipment with appropriate technology such as Automatic Transfer Switch (ATS), solar panels, inverters, batteries, solar charge controllers and other supporting equipment. This PKM program has a focus on managing backup power systems in vaccine cabinets using solar power plants
\end{abstract}

Keywords: Vaccine Cabinet, Solar Power Plant, Sindangbarang Health Center

\begin{abstract}
ABSTRAK
Kestabilan temperatur pada vaksin perlu dirancang sedemikian rupa untuk dapat menjaga kualitas dari vaksin tersebut. Dimana vaksin umumnya ditaruh pada kulkas khusus dengan temperatur dalam sekitar $+2^{0} \mathrm{C}-+8^{0} \mathrm{C}$. Kondisi jaringan listrik di daerah Bogor yang terkadang mengalami pemadaman dalam waktu yang cukup lama dapat menyebabkan tidak tersuplainya listrik untuk kulkas vaksin. Untuk jangka waktu yang cukup lama, kondisi ini dapat menyebakan menurunnya kualitas vaksin sehingga tidak bisa diberikan pada warga. Sehingga Tim P2M ITPLN berinisiatif untuk merancang sebuah penyimpanan daya yang dapat menjaga ketersediaan listrik bagi kulkas vaksin. Kegiatan ini merupakan penerapan teknologi yang sangat berguna bagi masyarakat kelurahan Bogor, terutama bagi Puskesmas Sindangbarang Bogor terkait dengan peracangan cadangan daya khususnya untuk lemari vaksin. Sistem cadangan daya ini menggunakan berbagai peralatan dengan teknologi tepat guna seperti Automatic Transfer Switch (ATS), panel surya, inverter, baterai, solar charge controller dan beberapa peralatan pendukung lainnya. Program PKM ini mempunyai fokus kepada pengelolaan sistem daya cadangan pada lemari vaksin menggunakan Pembangkit Listrik Tenaga Surya.
\end{abstract}

Kata kunci: Lemari Vaksin, Pembangkit Listrik Tenaga Surya, Puskesmas Sindangbarang 


\section{PENDAHULUAN}

Pusat Kesehatan Masyarakat, disingkat Puskesmas, adalah fasilitas pelayanan kesehatan yang menyelenggarakan upaya kesehatan masyarakat dan upaya kesehatan perseorangan tingkat pertama, dengan lebih mengutamakan upaya promotif dan preventif, untuk mencapai derajat kesehatan masyarakat yang setinggi-tingginya.[1] Dalam meningkatkan kesehatan dan kualitas hidup masyarakat maka banyak kegiatan pokok yang dilakukan oleh Puskesmas. Pelaksanaan kegiatan pokok Puskesmas diarahkan kepada keluarga sebagai satuan masyarakat terkecil dan dilaksanakan dengan pendekatan Pembangunan Kesehatan Masyarakat Desa. Puskesmas mempunyai jaringan kesehatan yang luas terutama di pedesaan sehingga dapat menjangkau masyarakat di wilayah kerjanya secara merata.

Puskesmas Sindangbarang merupakan Pusat Pelayanan Kesehatan Masyarakat di daerah Bogor Barat. Wilayah kerja dari Puskemas ini mencakup 194 Rukun Tetangga yang tersebar pada 5 kelurahan. Saat ini Puskesmas Sindangbarang memiliki layanan Kesehatan yang komprehensif mencakup pemeriksaan umum, pemeriksaan gigi dan mulut, imunisasi, keluarga bernecana, Kesehatan jiwa, dan laboratoium dll. Salah satu peran Puskesmas dalam menjaga Kesehatan masyarakat adalah memberikan imunisasi kepada masyarakat khususnya balita. Imunisasi merupakan metode memasukkan bakteri atau virus yang sudah dilemahkan ke dalam tubuh melalui suntikan. Diman program imuniasi merupakan tahapan wajib yang harus dilalui balita untuk membentuk sistem kekebalan dari penyakit seperti difteri, tetanus, hepatitis, dll. Imunisasi yang dirancang oleh pemerintah diberikan secara bertahap sejak bayi baru lahir sampai usia dua tahun.

Puskemas selaku agen yang berperan dalam memberikan imunisasi perlu menjaga kualitas vaksin yang akan diberikan. Penyimpanan vaksin perlu diperhatikan karena akan mempengaruhi keefektivan vaksin yang akan diberikan. Berdasarkan standar dari Departemen Keseharan Republik Indonesia, vaksin perlu disimpan dalam lemari es dengan suhu sekitar $2^{\circ} \mathrm{C}-8^{\circ} \mathrm{C}$. Puskemas perlu memastikan agar listrik yang menjadi suplai daya lemari vaksin tetap terjaga. Dimana kondisi ini agak menyulistkan karena PLN sebagai sumber listrik satu satunya pada Puskemas Sindangbarang terkadang melakukan pemadaman.

Untuk mengatasi permasalah tersebut Puskesmas telah menyediakan Generator Set sebagai upaya cadangan daya nya. Namun pada kenyatannya pengoprasian genset yang membutuhkan waktu menjadikan adanya jeda waktu yang cukup siginifikan bagi peralatan vaksin tersebut. Salah satu cadangan sumber listrik yang handal dan dapat bekrja secara cepat adalah Pembangkit Listrik Tenaga Surya (PLTS). Disamping handal sebagai sebuah sumber listrik, PLTS merupakan energi yang ramah lingkungan dan pemakaiannya dapat bertahan selama 20 tahun. Pemanfaatan PLTS pun sudah banyak dilakukan seperti penerangan jalan[2]-[4] dan pengairan [5], [6]

\section{METODE}

\subsection{Survei Kebutuhan Teknis Mitra}

Survei mengenai solusi yang akan diberikan pada mitra telah dilaksankan sebelum penyusuna proposal, namun survei lanjutan terkait kebutuhan teknis yang akan diperlukan dalam pembangunan sistem daya cadangan berbasis panel surya. Tim melakukan diskusi mengenai kebutuhan daya dari kulkas vaksin untuk menentukan spesifikasi sistem back up. Didapatkan bahwa kebutuhan daya dari kulkas vaksin adalah 310W dan lama cadangan yang diperlukan sekitar 3-5 jam. Pengetahuan akan kebutuhan daya ini sangat penting karena akan menentukan kapasitas dari komponen back up daya yang diperlukan. 


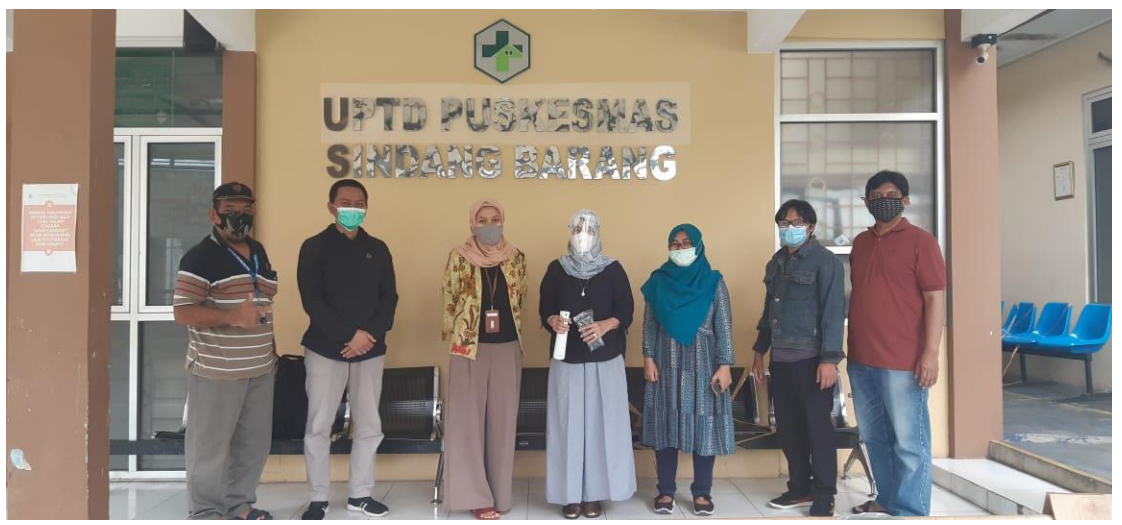

Gambar 1. Tim P2M Melakukan Survei Teknis

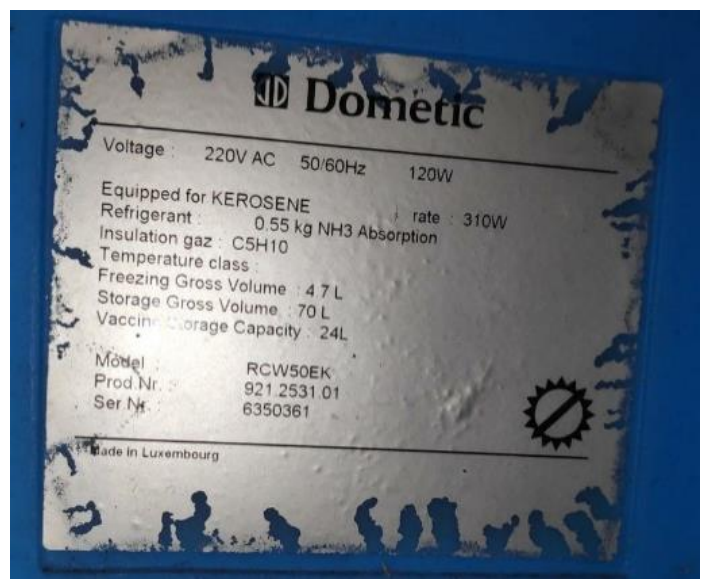

Gambar 2. Spesifikasi Kulkas Vaksin

Lokasi peletakkan panel surya dan panel box, dimana berdasrkan diskusi dan peninjauan panel surya akan diletakkan diatas canopy area teras puskesmas seperti terlihat pada Gambar 3.

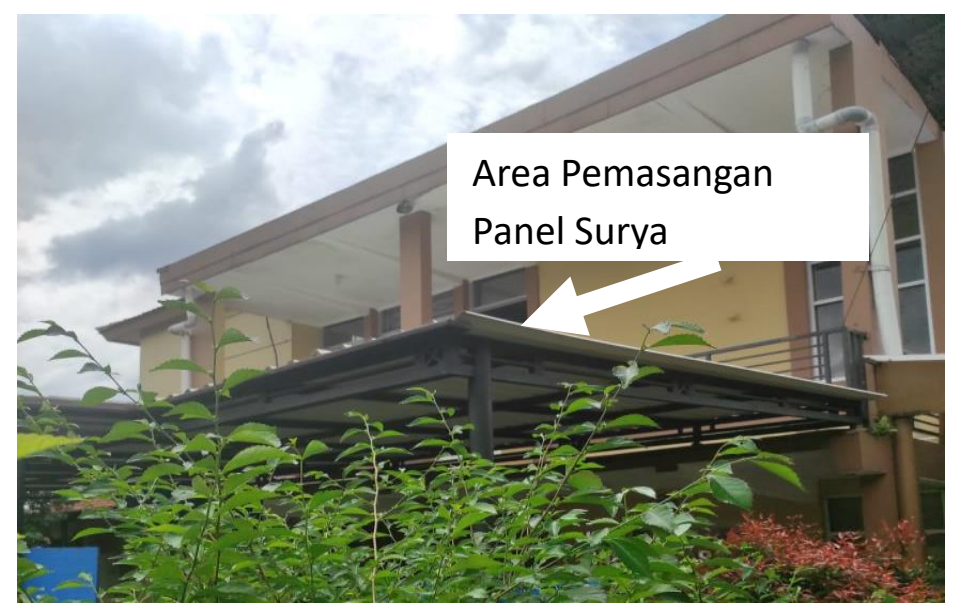

Gambar 3. Lokasi Pemasangan Panel PLTS

Sedangkan panel box yang berisi solar charge controller, inverter, dan alat alat kendali lainnya dileatkkan di ruangan yang sama dengan kulkas vaksin yang digamabrkan pada Gambar 4. Dengan 
mengetahui lokasi pemasangan panel box dan panel surya spesifikasi dari kabel, dimensi maksimal dari panel box dapat ditentukan.

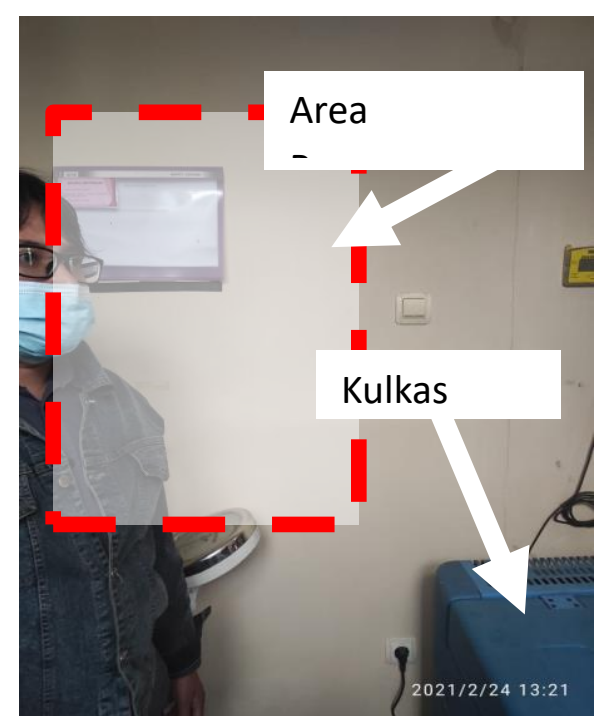

Gambar 4. Lokasi Pemasangan Panel Box

\subsection{Perancangan Sistem}

Berdasarkan informasi yang didapatkan terkait kapasitas kapasitas kulkas vaksin dan lama waktu daya cadangan yang diperlukan, disusun sebuah rancangan sistem daya cadangan berbasis panel surya. Adapun komponen-komponen yang diperlukan antara lain:

1. MCB AC dan DC

Sebagai pengaman rangkaian Ketika terjadi hubung singkat maupun beban lebih.

2. Solar Panel

Berfungsi untuk menerima sumber energi matahari dan mengkonversikannya menjadi energi listrik.

3. Solar Charge Controller

Berfungsi sebagai pengendali proses pengisian baterai oleh sumber energi surya

4. Baterai VRLA

Sebagai media penyimpanan energi listrik

5. Inverter

Mengubah arus DC yang tersimpan di baterai menjadi arus AC untuk mensuplai beban

6. Automatic Transfer Switch

Melakukan pengendalian antara sumber energi cadangan, sumber Energi listrik PLN, dan beban.

7. Low Voltage Disconnector

Memutuskan baterai dari beban supaya energi yang tersimpan di baterai tidak digunakan $100 \%$. Hal ini dimaksudkan agar baterai tetap awet, baterai yang digunakan sampai benar benar habis dapat mempersingkat waktu hidupnya. 


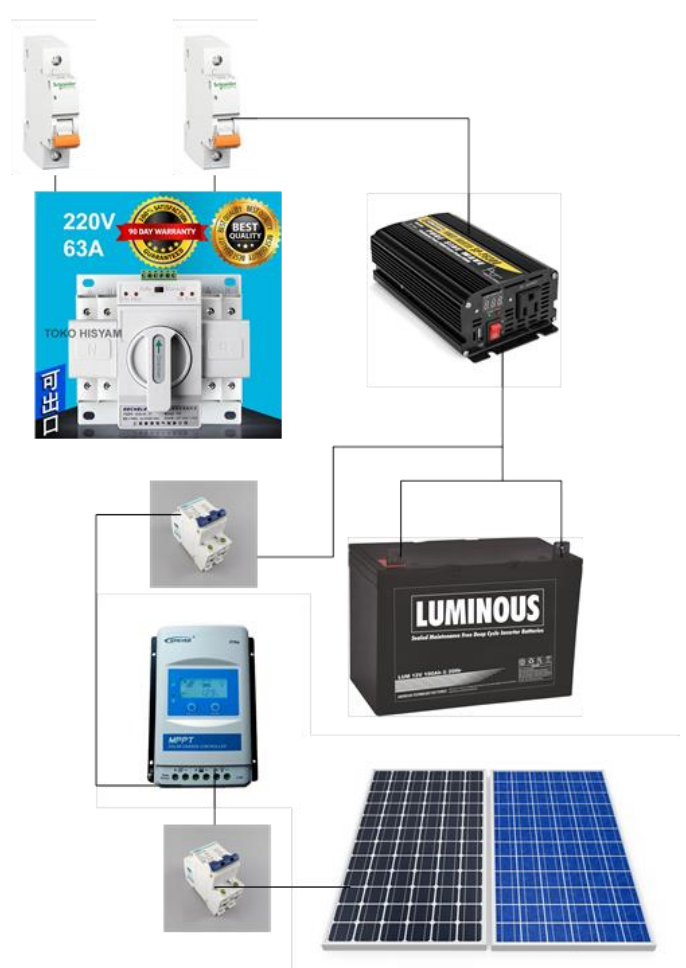

Gambar 5. Diagram Skematik Sistem Backup Daya Berbasis Panel Surya

Dengan mempertimbangkan kebutuhan daya dan lama daya cadangan diperlukan, disusunlah spesifikasi komponen.

Tabel 1. Kebutuhan Daya

\begin{tabular}{|c|c|c|c|c|c|}
\hline No & Item & Jumlah & $\begin{array}{c}\text { Daya } \\
(\mathrm{W})\end{array}$ & $\begin{array}{c}\text { Waktu } \\
(\mathrm{Jam})\end{array}$ & $\begin{array}{c}\text { Daya/Jam } \\
(\mathrm{Wh})\end{array}$ \\
\hline 1 & Kulkas Vaksin & 1 & 350 & 3 & 1050 \\
\hline \multicolumn{3}{|c|}{ TOTAL } & $\mathbf{3 5 0}$ & & $\mathbf{1 0 5 0}$ \\
\hline
\end{tabular}

Dengan mengasumsikan waktu penyerapan energi surya yang efektif di wilayah Bogor sekitar 5 jam per hari, maka kebutuhan WattPeak panel surya adalah Pembagian kebutuhan daya total per lama waktu penyinaran efektif.

$$
\text { Ppeak }=\frac{\text { Total KebutuhanDaya }}{\text { Waktu Penyinaran Efektif }}=1050 / 5=210 \mathrm{Wp}
$$

Apabila digunakan panel surya berukuran $100 \mathrm{Wp}$, maka jumlah panel surya yang dipelukan adalah $(210 \mathrm{Wp} / 100 \mathrm{Wp}=2.1$ Panel 3) 3 Panel yang terhubung paralel. Setelah jumlah panel ditentukan, komponen lain yang perlu diketahui kapasitasnya adalah baterai. Kapasitas baterai yang diperlukan bergantung dengan kebutuhan beban dan lama waktu daya cadangan dibutuhkan. Diketahui kebutuhan energi yang tersimpan sebesar $1050 \mathrm{Wh}$ maka apabila digunakan baterai dengan kapasitas 100 Ah dan level tegangan $12 \mathrm{~V}$, maka total baterai yang diperlukan adalah 3 buah sesuai dengan perhitungan di bawah.

$$
N \text { baterai }=\frac{\text { Kebutuhan Enegi }}{V_{\text {baterai }} \times I_{\text {baterai }} \times \text { Kapasitas Baterai Optimum }}
$$




$$
\text { Nbaterai }=\frac{1050 \mathrm{Wh}}{100 \mathrm{Ah} \times 12 \mathrm{~V} \times 30 \%}=2.9 \sim 3
$$

Perhitungan kapasitas solar charge controller bergantung dari kapasitas arus hubung singkat panel surya dan banyaknya panel yang terhubung paralel. Dengan diketahui arus hubung singkat panel surya sebesar 6.05 A dan digunakan 3 panel surya yang terhubung parallel maka kapasitas solar charge controller minimum adalah:

$$
\begin{gathered}
\text { Kapasitas SCC }=\text { Npanel } x \text { ISC } C_{\text {panel surya }} \\
\text { Kapasitas } S C C=3 \times 6.05=18.15 \mathrm{~A}
\end{gathered}
$$

Dengan mempertimbangkan margin keamanan, dipilih SCC dengan kapasitas 30 A. Perhitungan kapasitas inverter mempertimbangkan daya yang dibuthkan oleh beban. Dimana dengan diketahui kebutuhan daya kulkas vaksin sebeasr 350Watt dan dengan mempertimbangkan faktor keamanan maka diperlukan inverter dengan kapasitas minimal dua kali kebutuhan daya yaitu ( $350 \mathrm{x}$ $2=700) 700$ Watt. Berdasarkan perhitungan yang dilakukan didapatkan spesifikasi komponen untuk sistem daya cadangan seperti pada Tabel .

Tabel 2. Spesifikasi Komponen

\begin{tabular}{|l|l|c|c|}
\hline No & Komponen & Spesifikasi & Jumlah Alat \\
\hline $\mathbf{1}$ & Panel Surya & $100 \mathrm{Wp}$ & 3 \\
\hline $\mathbf{2}$ & Baterai & $100 \mathrm{Ah}$ & 3 \\
\hline $\mathbf{4}$ & Solar Chrage Controller & $30 \mathrm{~A}$ & 1 \\
\hline $\mathbf{5}$ & Inverter & $1000 \mathrm{~W}$ & 1 \\
\hline $\mathbf{6}$ & MCB AC 1 pole & $10 \mathrm{~A}$ & 1 \\
\hline $\mathbf{7}$ & MCB DC 2 pole & $20 \mathrm{~A}$ & 1 \\
\hline $\mathbf{8}$ & MCB DC 2 pole & $10 \mathrm{~A}$ & 1 \\
\hline $\mathbf{9}$ & Automatic Transfer Switch & $>10 \mathrm{~A}$ & 1 \\
\hline $\mathbf{1 0}$ & Low Voltage Disconnector & & 1 \\
\hline
\end{tabular}

\section{HASIL DAN PEMBAHASAN}

Kegiatan pemasangan sistem daya cadangan dilakukan pada tanggal 4 Juni 2021 oleh seluruh anggota Tim P2M dibantu dengan dua orang tukang. Dalam pelaksanannya tim dibagi menjadi tiga kelompok utama yaitu pemasangan panel box, pemasangan solar panel, dan dokumentasi.

Panel box dan baterai dipasang di ruangan yang sama dengan kulkas vaksin untuk memudahkan perawatan. Output ATS dihubungkan dengan stop kontak yang akan mensuplai daya untuk kukas vaksin. Namun untuk keamanan, output ATS perlu melewati MCB AC 20 A sebelum terhubung ke stop kontak. Hal ini dimaksudkan apabila terjadi kelebihan pembebanan atau hubung singkat pada area beban, tidak akan merusak komponen ATS ataupun inverter.

Kabel dari baterai harus melewati MCB DC 20 A sebelum dihubungkan dengan slot input inverter. Sedangkan kabel dari solar panel sebelum terhubung dengan dengan slot input SCC harus melewati MCB DC 10 A. Peran MCB sangat krusial karena menghindari kerusakan komponen komponen yang berada dalam panel box. 


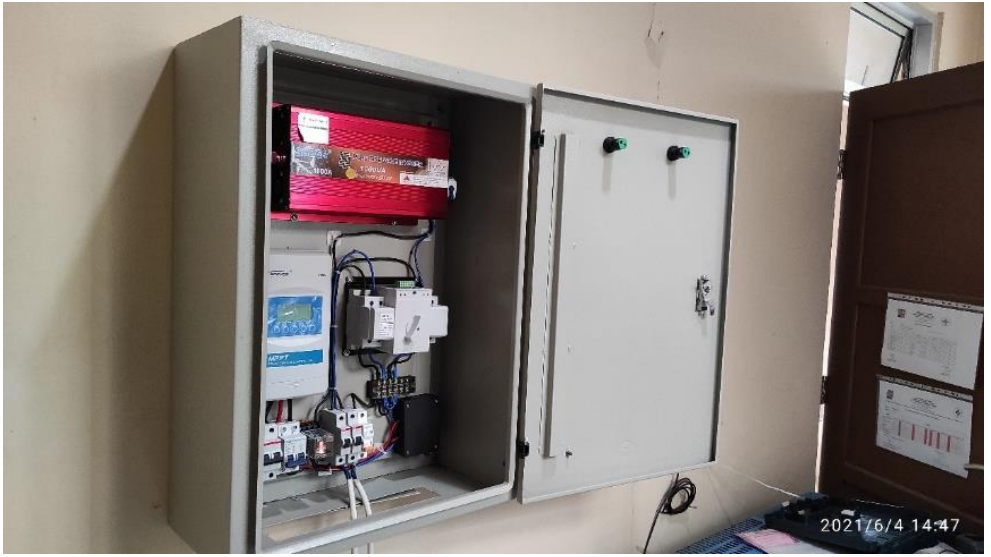

Gambar 6. Pemasangan Panel Box

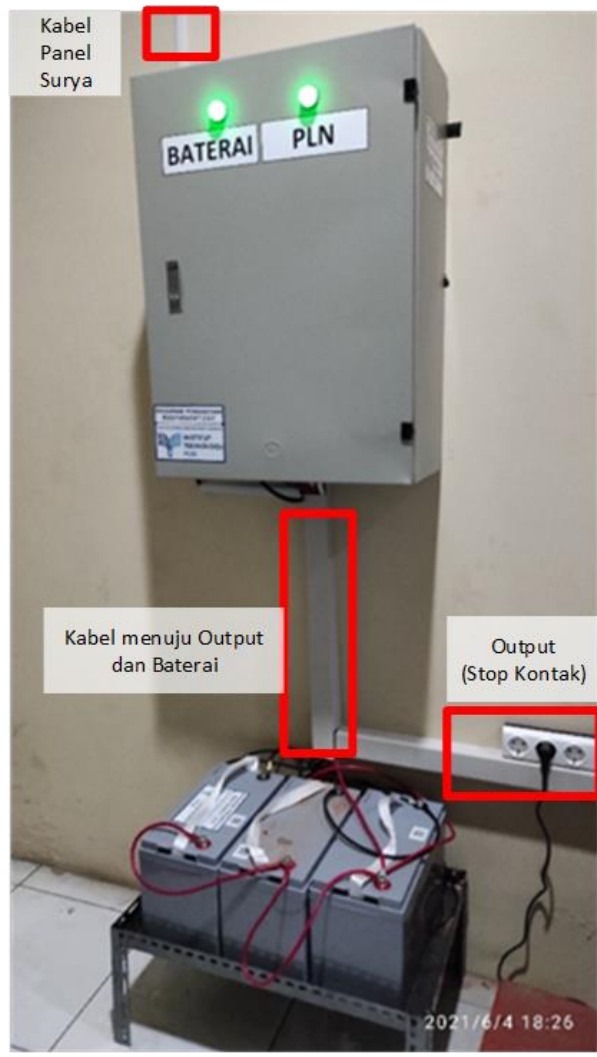

Gambar 7. Output dan Input Panel Box

Solar panel ditaruh di bagian luar puskesmas untuk mendapatkan sinar matahari yang cukup. Solar panel disusun secara parallel supaya tegangan keluran sama dengan tegangan input scc. Panel ditaruh dalam frame baja ringan yang terpasang pada atap selasar puskesmas supaya menccegah panel beprindah tempat atau jatuh ketika ada angin yang besar. 


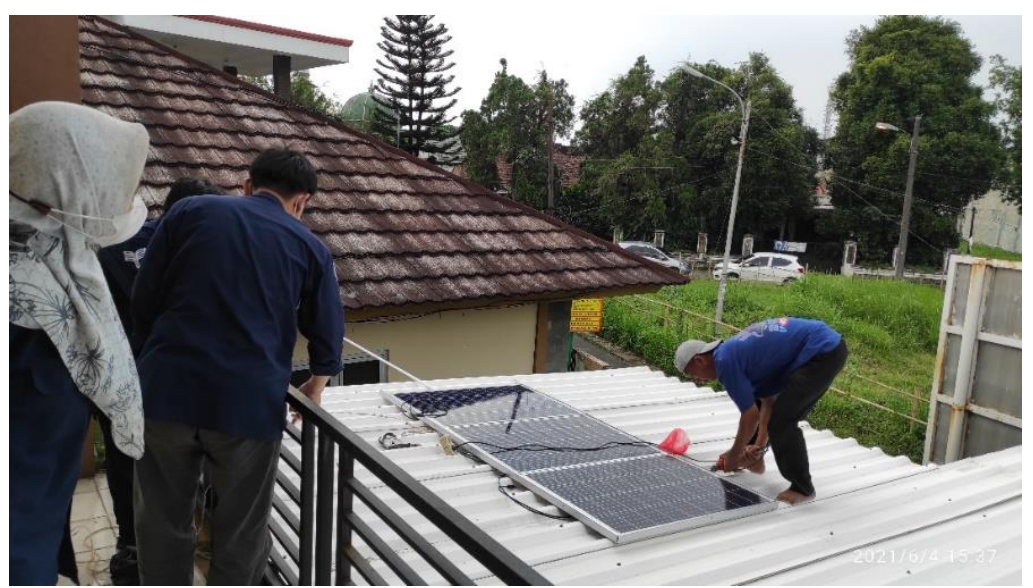

Gambar 8. Pemasangan Solar Panel

\section{KESIMPULAN}

Dengan diadakannya kegiatan ini, lemari vaksin pada Puskemas Sindangbarang dapat tetap bekerja walau terjadi pemadaman. Hal ini sangat penting mengingat vaksin harus selalu berada dalam kondisi dingin untuk menjaga efektivitasnya. Sistem daya cadangan yang menggunakan panel surya merupakan solusi yang inovatif dan efektif dalam menjaga suplai listrik ke lemari vaksin.

\section{SARAN}

Kegiatan ini dapat diterapkan pada Puskemas lain yang memiliki permasalahan yang serupa dimana sering terjadi pemadaman namun belum ada sistem daya cadangan yang memadai. .

\section{UCAPAN TERIMA KASIH}

Penulis mengucapkan terima kasih kepada Institut Teknologi PLN dan Puskesmas Sindangbarang Bogor yang telah memberi dukungan yang membantu pelaksanaan kegiatan pengabdian pada masyarakat.

\section{DAFTAR PUSTAKA}

[1] Kemenkes, Peraturan Menteri Kesehatan Republik Indonesia Nomoe 75 Tahun 2014. 2014.

[2] K. T. Mauriraya, R. Afrianda, A. Fernandes, A. Makkulau, D. P. Sari, and N. Kurniasih, "Edukasi Pemanfaatan PLTS untuk Penerangan Jalan Umum Di Desa Cilatak Kecamatan Ciomas Kabupaten Serang Banten,” Terang, vol. 3, no. 1, pp. 92-99, 2020.

[3] Y. Simamora, A. Senen, T. W. Oktaviana Putri, and D. Anggaini, "Rancang Bangun Lampu Jalan Tenaga Surya Pada Jembatan Penghubung Desa Di Kabupaten Lebak Banten,” Terang, vol. 2, no. 2, pp. 160-168, 2020.

[4] S. Azzahra, S. Samsurizal, C. Christiono, and M. Fikri, "Pemasangan Lampu Jalan dan Pembangunan Pembangkit Listrik Berbasis Solar Cell Sebagai Prototype Pembelajaran Energi Terbarukan Di MA Al-Khairiyah Rancaranji," Terang, vol. 3, no. 1, pp. 100-105, 2020.

[5] A. Senen, "Perancangan Pemanfaatan Tenaga Surya untuk Penyaluran Air Bersih Bagi Pesantren Attuma'ninah Kab. Lebak, Banten,” Terang, vol. 3, no. 1, pp. 1-9, 2020.

[6] D. P. Sari, N. Kurniasih, and A. Fernandes, "Pemanfaatan Listrik Tenaga Surya Sebagai Pasokan Listrik Untuk Menghidupkan Mesin Pompa Air Masyarakat Dusun Cilatak, Desa Sukadana, Kecamatan Ciomas, Kabupaten Serang, Banten," Terang, vol. 3, no. 1, pp. 68-79, 2020 . 